\title{
ANALYSIS OF MORPHOLOGICAL VARIATION OF FOUR POPULATIONS OF MACROBRACHIUM ROSENBERGII (DE MAN, 1879) (CRUSTACEA: DECAPODA) IN SRI LANKA
}

\author{
D.H.N. Munasinghe* and G.G.N. Thushari \\ Department of Zoology, Faculty of Science, University of Ruhuna, Matara, Sri Lanka. \\ Accepted 30 May 2010
}

\begin{abstract}
Freshwater prawn Macrobrachium rosenbergii (De Man, 1879) is one of the most economically important crustacean species cultured within its' natural distribution and beyond. In Sri Lanka, Macrobrachium rosenbergii has gained a value as an important organism in aquaculture. In culturing programs, brood stocks are collected from the wild populations. Thus, wild stocks are important as an immediate resource for addressing diversity problems in cultured stocks. This study analysed intraspecific variation among four populations of $M$. rosenbergii using morphological data. Samples were collected from four localities (populations): Negombo lagoon, Bolgoda estuary, Walawe River estuary and Nilwala River estuary. Total of 179 individuals were analysed using 10 morphometric and 2 meristic parameters. To determine the significant difference of size standerdized morphometric parameters among four populations, One way analysis of variance (ANOVA) was used. To distinguish four populations, Discriminant Function Analysis (DFA) was performed using morphometric parameters. First two discriminate functions totally accounted for $88.9 \%(69.3 \%$ and $19.6 \%)$ variables. First discriminate function by itself identified nine morphometric characters as contributors for this analysis. According to the results of ANOVA, all morphometric characters were variable among four populations which indicated the availability of adaptive traits within the species. However, Discriminant Function Analysis failed to distinguish geographically separated four $M$. rosenbergii populations. The importance of collecting information on population diversity levels of economically valuable aquatic species when constructing aquaculture and conservation programs are discussed.
\end{abstract}

Key words: aquaculture, adaptive traits, population variation

\section{INTRODUCTION}

Giant fresh water Prawn Macrobrachium rosenbergii (De Man, 1879) is the largest known palaemonid in the world. The natural distribution of $M$. rosenbergii extends from western Wallace line to the southern part of Asia. Among crustacean, $M$. rosenbergii attracted more attention in the recent years which causes to expand its distribution not only within its natural range, but even the beyond (Mather \& de Bruyn, 2003). During past thirty years, the production of farmed $M$. rosenbergii was significantly increased and is expected that the production will be exceeded 400,000 tonnes by 2010 (FAO web site). Due to high abundance in natural water bodies in many countries of Asia, a significant fishery industry has been established based on the wild stocks of this economically important species (Mather \& de Bruyn, 2003). However, it is reported that the wild stocks of this species are declining rapidly due to over-harvesting, habitat-loss and increased pollution (New, 2000; Ng, 1997).

To improve and expand the freshwater prawn fishery, National Aquaculture Development Authority (NAQDA) in Sri Lanka has launched a free stocking program of $M$. rosenbergii in selected medium irrigation tanks. Fingerlings for stocking programs are collected from hatcheries and the brood stocks are collected from the wild populations. Thus, wild stocks are important as an immediate resource for addressing genetic diversity problems in cultured stocks. Most genetic variations represent by phenotypic characteristics. Therefore, evaluation of diversity within and among populations could be initiated through morphological studies.

Long, stout and robust $2^{\text {nd }}$ pair of periopod is a prominent feature of the genus Macrobrachium. Therefore, this character has

*Corresponding author's email: dhnm@zoo.ruh.ac.lk 
been taken into account in many morphological studies recorded on this genus (Holthuis, 1950, Bruce and Chace 1993, Suzuki and Kusamura 1997). However, pereiopods of prawns are regenerated appendages, which are mainly used in reproductive and agonistic behaviours, thus are subjected to damage during their activities. More often they shed their periopods during trapping and collecting processes. If these appendages are in regenerating stage, the data collect at this stage could lead to erroneous results. Therefore, this study is designed to investigate the intra-specific variations among four populations of $M$. rosenbergii in Sri Lanka using morphological data other than periopods.

\section{METHODOLOGY}

Giant freshwater prawn, $M$. rosenbergii samples were collected from four populations: Negombo lagoon (Ja Ela in figure 1), Bolgoda estuary, Walawe river estuary and Nilwala river estuary (Fig. 1). Sample collections were conducted from January to December 2008 with the help of fishermen. Fifty individuals were collected from each population and samples were preserved in $70 \%$ ethanol until the measurements were taken. Initially, twenty-four morphometric and two meristic parameters were measured and the data were examined for normality. All measurable characters were considered as morphometric parameters while teeth of the rostrum were counted as meristic parameters. Morphometric measurements were taken to the nearest $0.01 \mathrm{~cm}$ with the aid of rulers, vernier calliper and threads. Data for meristic characters were collected by observations and counting under naked eye.

Characters with missing data and data that skewed from normality test (even after transformed) were omitted from further analysis. Finally, data collected from ten morphometric and two meristic parameters (Fig. 2, Table 1) for 179 individuals from four populations were computed to perform Multivariate analysis.

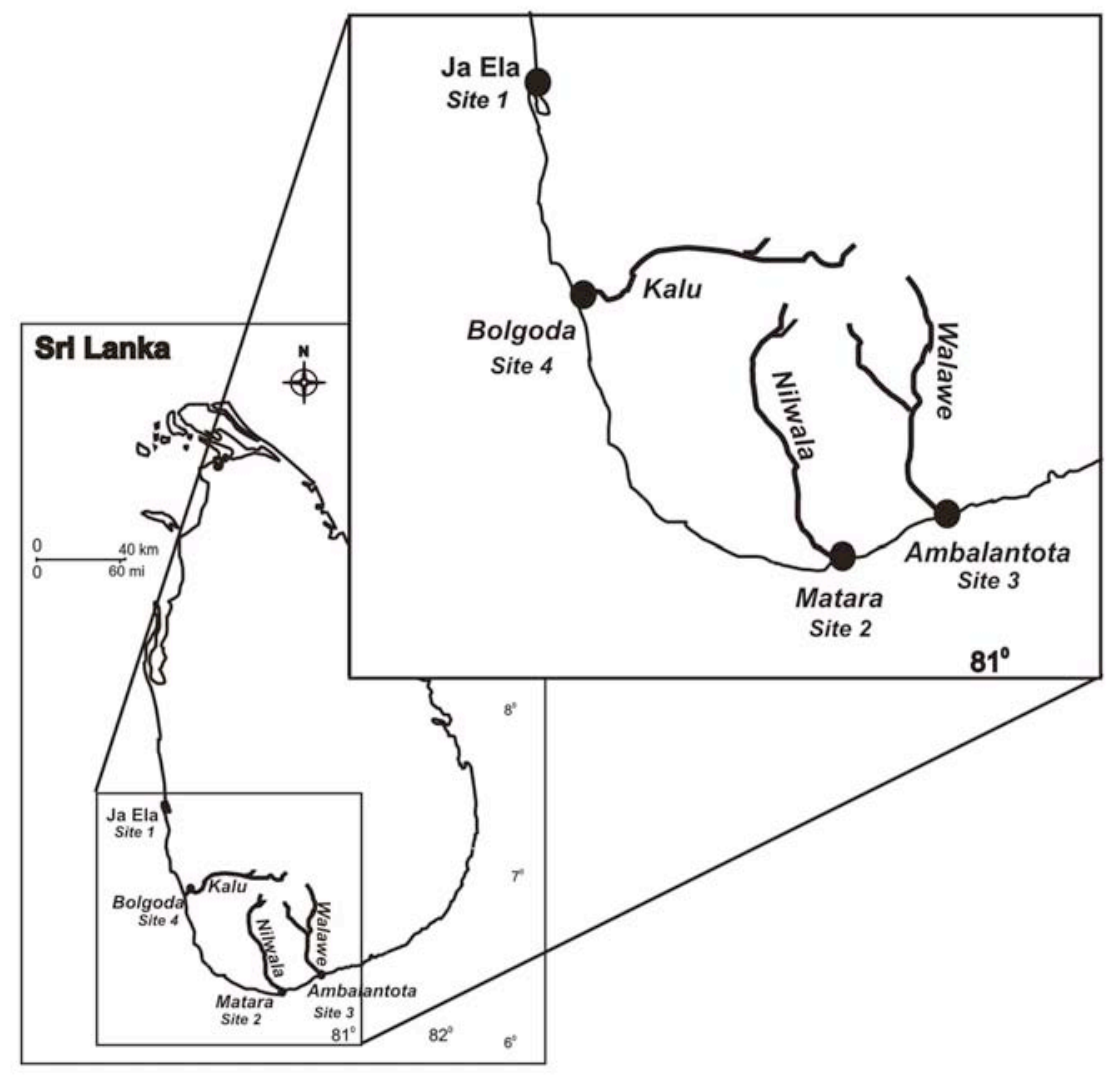

Figure 1. Map of Sri Lanka showing the sampling sites of Macrobrachium rosenbergii. 


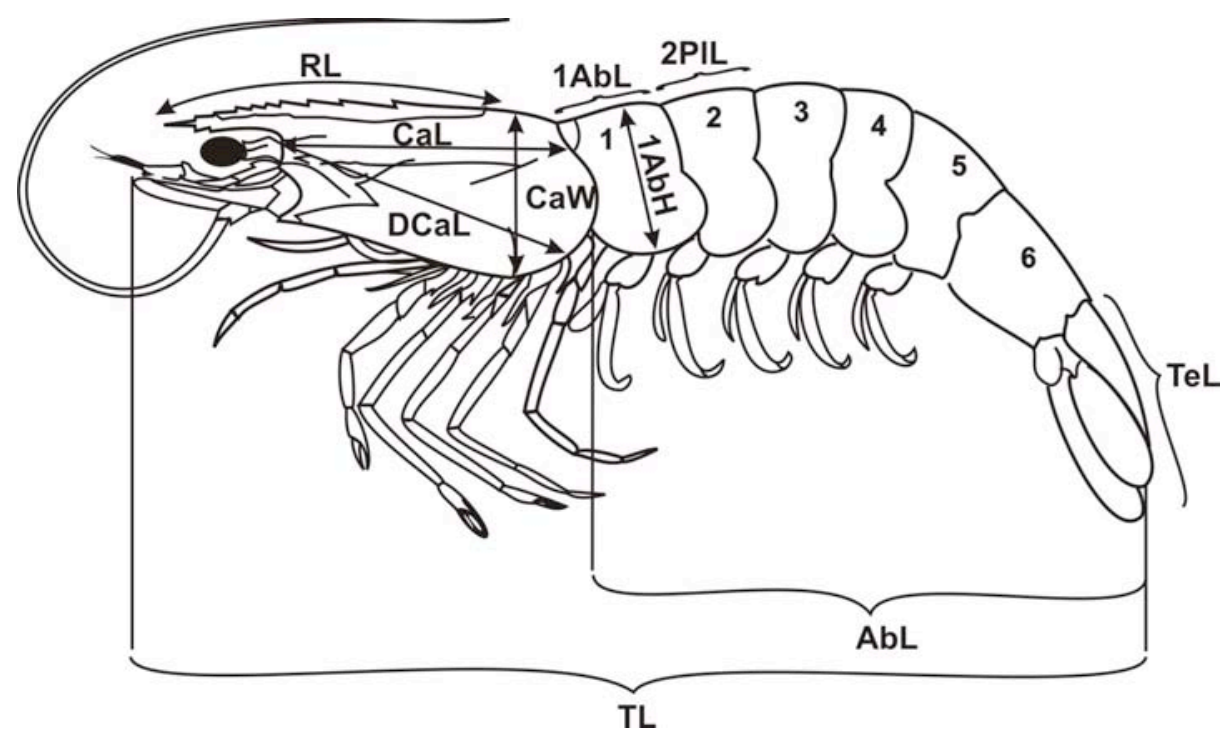

Figure 2. Schematic representation of Macrobrachium rosenbergii to show morphometric and meristic parameters used in the study. (Please refer Table 1 for abbreviations).

Table 1. Details of morphometric and meristic parameters of Macrobrachium rosenbergii used in the study.

\begin{tabular}{|c|c|c|}
\hline Variable & & Measurements and Counts \\
\hline \multicolumn{3}{|l|}{$\begin{array}{l}\text { Morphometric } \\
\text { parameters }\end{array}$} \\
\hline Total Length & TL & The length from tip of the antennule's plate to end of the telson* \\
\hline Abdominal Length & $\mathrm{AbL}$ & The length from the posterior end of the carapace to end of the telson* \\
\hline Length of Telson & TeL & The maximum length of the telson* \\
\hline Carapace Length & $\mathrm{CaL}$ & The length from the base of the eye stalk to posterior end of the Carapace* \\
\hline Carapace Width & $\mathrm{CaW}$ & The length of the maximum depth of the carapace*** \\
\hline $\begin{array}{l}\text { Diagonal Carapace } \\
\text { Length }\end{array}$ & $\mathrm{DCaL}$ & $\begin{array}{l}\text { The length from the base of the eye stalk to bottom of the posterior end of } \\
\text { carapace** }\end{array}$ \\
\hline $\begin{array}{l}\text { First Abdominal } \\
\text { Length }\end{array}$ & $1 \mathrm{AbL}$ & The maximum length of the first abdominal segment* \\
\hline $\begin{array}{l}\text { First Abdominal } \\
\text { Height }\end{array}$ & $1 \mathrm{AbH}$ & The maximum height of the first abdominal segment*** \\
\hline Rostral Length & RL & The length from the tip to the end of the rostrum* \\
\hline $\begin{array}{l}\text { Second Abdominal } \\
\text { Length }\end{array}$ & 2PIL & The maximum length of second abdominal segment* \\
\hline \multicolumn{3}{|l|}{ Meristic parameters } \\
\hline $\begin{array}{l}\text { Number of upper teeth } \\
\text { of Rostrum }\end{array}$ & No.U & Total count of upper teeth of the Rostrum \\
\hline $\begin{array}{l}\text { Number of lower teeth } \\
\text { of Rostrum }\end{array}$ & No.L & Total count of lower teeth of the Rostrum \\
\hline
\end{tabular}

* - Horizontal length measurements $\quad * *$ - Diagonal length measurements $\quad * * *$ - Vertical length measurements

All morphometric measurements were size standardized using regression and residual analysis method (Thrope, 1976). The regression procedure uses the 'common' slope to estimate the relationship between the dependent variable (each morphometric parameter) and the independent /reference parameter (CaL). Therefore, any particular value of $\mathrm{CaL}\left(\mathrm{X}_{1}\right)$, a value for any morphometric can be predicted $\left(\mathrm{y}_{2}\right)$ using this relationship. The estimated pooled mean value for the carapace length $(\mathrm{CaL})$ was used to determine the predicted value for 
the dependent $\left(\mathrm{Y}_{1}\right)$ parameter. For a given specimen, the difference between this predicted and observed value $\left(\mathrm{Y}_{1}-\mathrm{Y}_{2}\right)$ was entered for the analysis. Utility of size standardized data is important in this analysis as differences among groups for measured parameters may be biased due to growth stages and the sampling technique. One- way analysis of variance (ANOVA) was carried out to test the variability of morphometric characters among spatially separated four populations. This followed Turkey HSD multiple comparisons test for unequal sample size $(\mathrm{p}<0.05)$ (Zar, 1984). The significance of meristic characters among populations was estimated using KruskalWallies nonparametric test. Discriminant Function Analysis (DFA) was performed to determine the most reliable morphological characters that are important to distinguish populations. Wilks' Lambda was used to test the significance of the discriminant function as a whole. Mahalanobis Squared Distance $\left(D^{2}\right)$ was included in DFA and the distance between cases and the centroid for each group in attributed space was determined (Garson, 2008). Canonical scores derived from DFA analysis were plotted in two-dimensional spaces for visual detection of the separation of populations. All analysis was performed using SPSS (V. 16.0) or MINITAB (Version. 13.0) statistical packages.

\section{RESULTS}

The summary of the statistical analysis of collected data from four populations for 10 morphometric and 2 meristic parameters are given in Table 2. According to the data, the length of the reference parameter (Carapace length) ranged from 0.39 to 1.04 and the highest value was recorded from the Negombo lagoon population. The statistical results of ANOVA revealed significant variability among the four populations for all morphometric parameters $(p<0.05)$. According to the results of KruskalWallies nonparametric test, a significant difference cannot be observed for the number of upper and lower teeth of the rostrum among Populations ( $\mathrm{p}>0.05)$.

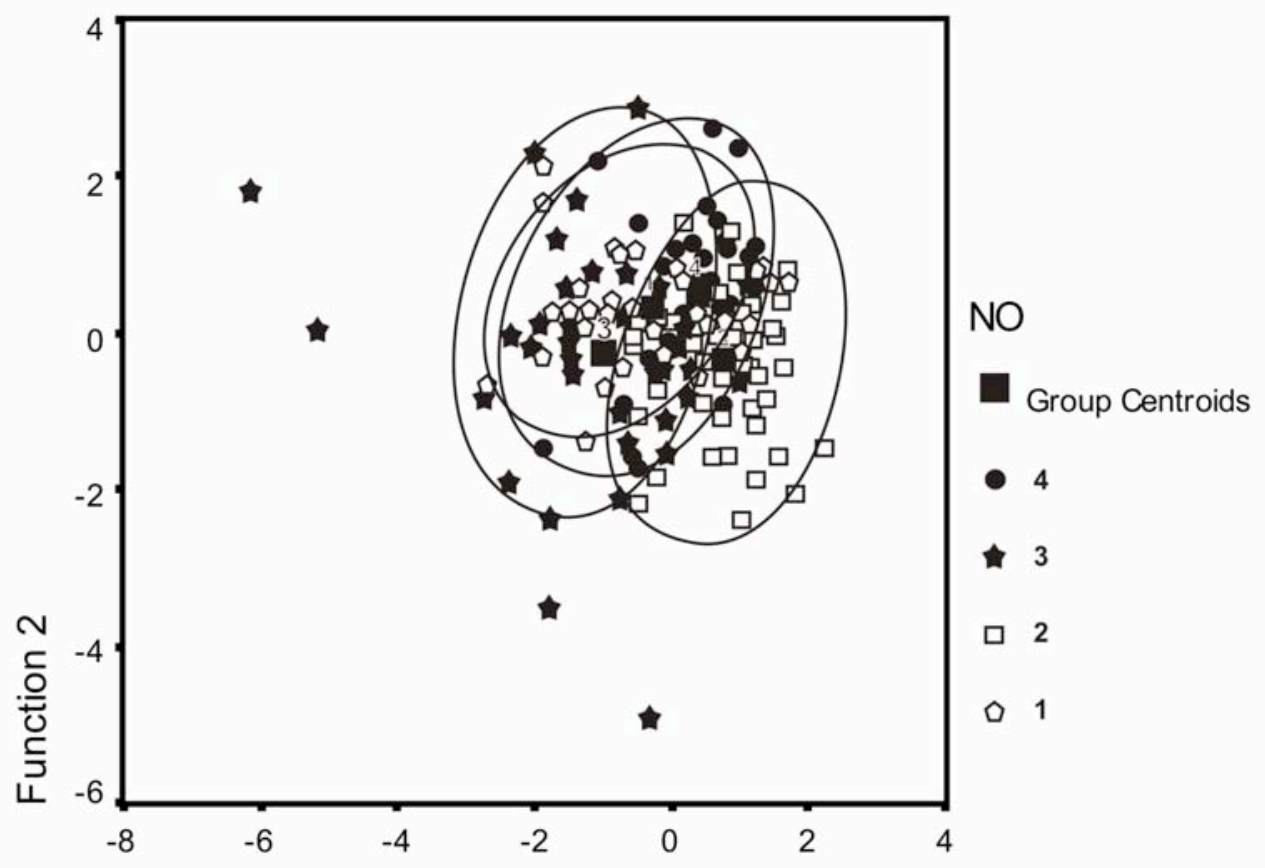

\section{Function 1}

Figure 3. The Cluster Plot between $1^{\text {st }}$ and $2^{\text {nd }}$ Discriminant Functions for four populations of Macrobrachium rosenbergii. 
Table 2. Summary of the statistical analysis of morphometric (1-10) and meristic (I-II) parameters of Macrobrachium rosenbergii $(\mathrm{N}=$ Number of samples used in each population)

\begin{tabular}{|c|c|c|c|c|c|c|c|c|c|c|c|c|}
\hline \multirow[b]{2}{*}{ Variable } & \multicolumn{3}{|c|}{$\begin{array}{l}\text { Negombo Lagoon (Site } \\
01)(\mathrm{N}=46)\end{array}$} & \multicolumn{3}{|c|}{ Nilwala River (Site 02)(N=45) } & \multicolumn{3}{|c|}{ Walawe River (Site 03)(N=45) } & \multicolumn{3}{|c|}{ Bolgoda Estuary (Site 04)(N=43) } \\
\hline & Mean \pm SD & Maxim. & Minim. & Mean \pm SD & Maxim. & Minim. & Mean \pm SD & Maxim. & Minim. & Mean \pm SD & Maxim. & Minim. \\
\hline 1. Lg TL & $\begin{array}{l}1.3651 \pm \\
0.1169\end{array}$ & 1.5798 & 1.1673 & $\begin{array}{l}1.4803 \pm \\
0.0631\end{array}$ & 1.5855 & 1.3522 & $\begin{array}{l}1.3362 \pm \\
0.1507\end{array}$ & 1.5729 & 0.9777 & $\begin{array}{l}1.4352 \pm \\
0.0654\end{array}$ & 1.5717 & 1.3324 \\
\hline 2. $\mathrm{Lg} \mathrm{AbL}$ & $\begin{array}{l}1.1394 \pm \\
0.1080\end{array}$ & 1.3345 & 0.9395 & $\begin{array}{l}1.2404 \pm \\
0.0525\end{array}$ & 1.3424 & 1.1239 & $\begin{array}{l}1.0959 \pm \\
0.1279\end{array}$ & 1.2833 & 0.7243 & $\begin{array}{l}1.2012 \pm \\
0.0625\end{array}$ & 1.3424 & 1.0607 \\
\hline 3. Lg TeL & $\begin{array}{l}0.4304 \pm \\
0.0973\end{array}$ & 0.6532 & 0.2788 & $\begin{array}{l}0.5093 \pm \\
0.0813\end{array}$ & 0.6435 & 1.5000 & $\begin{array}{l}0.4016 \pm \\
0.1430\end{array}$ & 0.6532 & 0.1461 & $\begin{array}{l}0.47449 \pm \\
0.06199\end{array}$ & 0.60206 & 0.34242 \\
\hline 4. $\mathrm{Lg} \mathrm{CaL}$ & $\begin{array}{l}0.7464 \pm \\
0.1495\end{array}$ & 1.0414 & 0.4914 & $\begin{array}{l}0.8775 \pm \\
0.0879\end{array}$ & 1.0212 & 0.7243 & $\begin{array}{l}0.7298 \pm \\
0.1930\end{array}$ & 1.0212 & 0.3979 & $\begin{array}{l}0.8464 \pm \\
0.0749\end{array}$ & 1.0000 & 0.7404 \\
\hline $5 \mathrm{Lg} \mathrm{CaW}$ & $\begin{array}{l}0.6571 \pm \\
0.1386\end{array}$ & 0.9395 & 0.4150 & $\begin{array}{l}0.7869 \pm \\
0.0877\end{array}$ & 0.9294 & 0.6335 & $\begin{array}{l}0.6358 \pm \\
0.1899\end{array}$ & 0.9494 & 0.3010 & $\begin{array}{l}0.7517 \pm \\
0.0789\end{array}$ & 0.8865 & 0.6128 \\
\hline 6. Lg DCaL & $\begin{array}{l}0.8032 \pm \\
0.1452\end{array}$ & 1.1038 & 0.5798 & $\begin{array}{l}0.9311 \pm \\
0.0984\end{array}$ & 1.0864 & 0.7782 & $\begin{array}{l}0.7879 \pm \\
0.1962\end{array}$ & 1.0899 & 0.4771 & $\begin{array}{l}0.8954 \pm \\
0.0913\end{array}$ & 1.0645 & 0.7404 \\
\hline 7. $\mathrm{Lg} 1 \mathrm{AbL}$ & $\begin{array}{l}1.0556 \pm \\
0.0945\end{array}$ & 1.2844 & 0.8751 & $\begin{array}{l}1.1561 \pm \\
0.0585\end{array}$ & 1.3010 & 1.0414 & $\begin{array}{l}1.0545 \pm \\
0.1578\end{array}$ & 1.2730 & 0.6990 & $\begin{array}{l}1.1146 \pm \\
0.0592\end{array}$ & 1.2175 & 0.9542 \\
\hline 8. $\mathrm{Lg} 1 \mathrm{AbH}$ & $\begin{array}{l}1.6190 \pm \\
0.0919\end{array}$ & 1.7800 & 1.4624 & $\begin{array}{l}1.7197 \pm \\
0.0442\end{array}$ & 1.7976 & 1.6101 & $\begin{array}{l}1.5784 \pm \\
0.1711\end{array}$ & 1.7462 & 0.6435 & $\begin{array}{l}1.6563 \pm \\
0.0867\end{array}$ & 1.7672 & 1.2175 \\
\hline 9. Lg RL & $\begin{array}{l}0.9165 \pm \\
0.1010\end{array}$ & 1.0960 & 0.7160 & $\begin{array}{l}0.9982 \pm \\
0.1094\end{array}$ & 1.4548 & 0.6990 & $\begin{array}{l}0.8938 \pm \\
0.1497\end{array}$ & 1.1239 & 0.6021 & $\begin{array}{l}0.9648 \pm \\
0.0736\end{array}$ & 1.0969 & 0.7924 \\
\hline 10. Lg 2PIL & $\begin{array}{l}1.3651 \pm \\
0.1398\end{array}$ & 1.5711 & 1.0000 & $\begin{array}{l}1.4701 \pm \\
0.0540\end{array}$ & 1.5711 & 1.3170 & $\begin{array}{l}1.3430 \pm \\
0.1394\end{array}$ & 1.6048 & 1.0414 & $\begin{array}{l}1.3487 \pm \\
0.0675\end{array}$ & 1.5502 & 1.2109 \\
\hline I. No.U & $\begin{array}{l}13.0 \pm \\
1.183\end{array}$ & 15.0 & 9.0 & $\begin{array}{l}12.0 \pm \\
2.167\end{array}$ & 16.0 & 7.0 & $\begin{array}{l}13.0 \pm \\
1.534\end{array}$ & 16.0 & 8.0 & $\begin{array}{l}13.0 \pm \\
1.340\end{array}$ & 15.0 & 8.0 \\
\hline II. No. L & $\begin{array}{l}12.0 \pm \\
1.414\end{array}$ & 7.00 & 14.0 & $\begin{array}{l}11.0 \pm \\
2.316\end{array}$ & 14.0 & 6.0 & $\begin{array}{l}12.0 \pm \\
1.886\end{array}$ & 15.0 & 3.0 & $\begin{array}{l}12.0 \pm \\
1.922\end{array}$ & 14.0 & 6.0 \\
\hline
\end{tabular}


Three discriminant functions were revealed according to the canonical scores by DFA analysis. According to the respective Eigenvalues, the first and the second functions accounted for $69.3 \%$ and $19.6 \%$ respectively. As the third function accounted for very low value $(11.1 \%)$, only first two functions were taken into consideration. The highest discrimination is given by the first discriminate function by itself, which identified nine size corrected morphometric characters as significant contributors for the separation of the populations (Table 3). Among them, the highest correlation is recorded for the Abdominal Length (AbL) (0.892) while the lowest is recorded for the Rostral Length (RL) (0.527). According to the basic classification given by the DFA, the highest value can be observed for Nilwala River estuary population (Site 02$)(77.4 \%)$ while the lowest value for Bolgoda estuary population (Site 04) $(31.6 \%)$ whereas those for the Ja-Ela population (Site 01) and Walawe river estuary population (Site 03) were scored $56.5 \%$ and $56.1 \%$ respectively. Derived discriminant functions using size-corrected morphometric parameters identified nine parameters that can be considered as significant contributors (Wilk's Lamda $=0.542, \quad \mathrm{P}=0.000)$. Mahalanobis Squared Distances indicated that two third of the cases in each group have less than 0.05 chance of gathering around the relative centroids of each group $\left(D^{2}>1.96\right)$.

Table 3. Correlations between discriminating variables (parameters) and standardized canonical discriminant functions of Macrobrachium rosenbergii

\begin{tabular}{|l|l|l|l|}
\hline \multirow{2}{*}{ Parameter } & \multicolumn{2}{|l}{ Functions } \\
\cline { 2 - 4 } & 1 & 2 & 3 \\
\hline $\mathrm{AbL}$ & $0.892 *$ & -0.120 & 0.133 \\
$\mathrm{TL}$ & $0.784 *$ & -0.209 & 0.247 \\
$1 \mathrm{AbH}$ & $0.701 *$ & -0.301 & -0.073 \\
$\mathrm{PIL}$ & $0.711^{*}$ & -0.148 & 0.376 \\
$\mathrm{CaW}$ & $0.680 *$ & -0.123 & 0.381 \\
$\mathrm{DCaL}$ & $0.608 *$ & -0.136 & 0.372 \\
$1 \mathrm{AbL}$ & $0.579 *$ & -0.317 & 0.344 \\
$\mathrm{TeL}$ & $0.595^{*}$ & -0.133 & 0.091 \\
$\mathrm{RL}$ & $0.527 *$ & -0.146 & 0.138 \\
\hline
\end{tabular}

* Largest absolute correlation between each variable and any discriminant function
The scatter-plot derived after plotting, $1^{\text {st }}$ and $2^{\text {nd }}$ Discriminant Functions for four populations of $M$. rosenbergii are given in Fig. 3. However, the plot indicated the overlapping of the populations and thus failed to distinguish the four geographically separated $M$. rosenbergii populations.

\section{DISCUSSION}

Morphometric variability among different geographical populations may be attributed due to distinct genetic structure and environmental conditions (Waldman et al., 1988). Therefore, animals with the same morphometric characters are often assured to constitute a stock and that has been utilized widely in stock differentiation in fisheries industry (Avsar, 1994). For the genus Macrobrachium, morphological diverse geographical groups are reported in the literature (Carini and Hughes, 2004; Short, 2004, Wowor and $\mathrm{Ng}, 2007$ ).

The current study indicates that meristic characters do not favour in intra-specific population studies of $M$. rosenbegii. Wowor and $\mathrm{Ng}$ (2007) also failed to distinguish closely related $M$. rosenbergii and $M$. dacqueti species using meristic characters. However, in previous studies, Cowles (1914) and Johnson (1973) indicated the usefulness of rostral teeth to distinguish the above two species. According to the results, the discriminant functions that were based on canonical scores failed to distinguish the four geographically separated $M$. rosenbergii populations. Although, the centroids for the four populations were clearly separated, the scatter plots for the four populations overlapped each other (Fig. 3). This was further confirmed by the results of Mahalanobis Squared Distances, which indicated the deviation of cases from centroids in each group $\left(\mathrm{D}^{2}>1.96\right)$. However, the observed morphometric differences indicated significant variability among the four populations. This may be due to local adaptations within populations as a result of environmental variability in different localities. Therefore, these populations could be considered as adaptive traits within the species and could be consider when applying conservation measures.

There is a possibility to some extent to mix populations of $M$. rosenbergii by sea currents as adult females arrive to spawn in estuaries. Especially, this can be occurred among the four 
sites due to their close proximity. However, genetic data are essential for clear understanding of the degree of variability among biogeographically separated $M$. rosenbergii populations. Past studies indicated that molecular genetic data are more reliable in estimating gene flow among populations and thus are important in identifying geographic variability among freshwater prawn populations (de Bruyn et al., 2004a, 2004b; Tong et al., 2000).

As Macrobrachium populations are declining, collection of information and conduction of this type of studies are important from a conservation point of view. In culturing programs, brood stocks are selected from wild populations, thus identification of geographically diverse $M$. rosenbergii populations are important. In the above cases morphological analyses are the fundamental approaches that have to be undertaken a priori. Most phenotypic variations arise due to genetic variations (Tzeng et al., 2001) and therefore, the combined approaches of morphometric and genetic analysis facilitate to recognize significantly divergent populations. These diverse populations could be treated as Management Units (MU) which can then be prioritized in conservation efforts.

\section{REFERENCES}

Avsar, D. (1994). A stock differentiation study of the sprat (Sprattus spuatus plalericus Risso) off the Southern Coast of the Black Sea. Fish Research. 19: 363-378.

Bruce, A. J. and Chace, F.A. (1993). The caridiean shrimps (Crustacea, Decapoda) of the Albatross Philippine Expedition; 1907-1910; part 6 Superfamily Palaemonidae. Smithsonian Contribution to Zoology 543: 1-152.

Carini, G. and Hughes, J.M. (2004). Population structure of Macrobrachium australiense (Decapoda: Palaemonidae) in Western Queensland, Australia: the role of contemporary and historical processes. Heredity 93: 350-363.

Cowles, R.P. (1914). Palaemons of the Philippine Islands. The Philippine Journal of Science (D) 9(4): 319-403.

De Bruyn M., Mather P.B., Wilson J.A., (2004 a). Huxley's line demarcates extensive genetic divergence between eastern and western forms of the giant freshwater prawn, Macrobrachium rosenbergii. Molecular Phylogenetics and Evolution 30: 251-257.

De Bruyn M., Mather P.B., Wilson J.C., (2004 b). Reconciling geography and genealogy; Phylogeography of giant freshwater prawns from the Lake Carpentaria region. Molecular Ecology 13: 3515-3526.

De Man J.G., (1879). On some species of the genus Palaemon Fabar. With descriptions of two new forms. Notes from the Royal Zoological Museum of the Netherlands at Leyden.1: 165184.

FAO web site: http://www.fao.org/fishery/culturedspecies/Macr obrachium rosenbergii/en

Garson, D. (2008) Constructed website on Discriminat Function Analysis-of the North Carolina State University(http://faculty.chass.ncsu.edu/garson/ PA765/discrim).

Holthuis, L.B. (1950). The Decapoda of the Siboga Expedition, Part X: The Palaemonidae collected by the Siboga and Snellius Expeditions, with remarks on other species, Part I: Subfamily Palaemoninae. In Siboga-Expeditie 39a: 268 pp.

Johnson, D.S. (1973). Notes on some species of the genus Macrobrachium; Crustacea ; Decapoda ; Caridea ; Palaemonidae. Journal of the Singapore National Academy of Science 3(3): 273-291.

Mather, P.B. and De Bruyn, M. (2003). Genetic diversity in wild stocks of the giant fresh water prawn; Macrobrachium rosenbergii: Implications for aquaculture and conservation. NAGA, World Fish Center Quarterly 26: 4-7.

New, M.B. (2000). History and global status of freshwater prawn farming; In; M.B. New and W.C. Valenti (Eds.), Freshwater prawn culture; the farming of Macrobrachium rosenbergii, Blackwell Science, Oxford: Pp. 1-11.

Ng, P.K.L. (1997). The conservation status of freshwater prawns and crabs in Singapore with emphasis on the Nature Reserves. Proceedings of the Nature Reserves Survey Seminar Garden's Bulletin Singapore 49: 267-272. 
Short, J.W. (2004). A revision of Australian river prawns, Macrobrachium; Crustacea: Decapoda: Palaemonidae. Hydrobiologia 525: 1-100.

Suzuki, H. and Kusamura, T. (1997). Reexamination of the diagnostic characters of two freshwater palemonid prawns, Macrobrachium nipponense (de Hann, 1849) and M. formosense (Bate, 1868) (Decapoda, Caridae) from Japan. Crustaceana 70: 831-839.

Thorpe, R.S. (1976). Biometric analysis of geographic variation and racial affinities. Biological Reviews 51: 407 - 452.

Tong, J.G., Chan, T.Y. and Chu, K.H. (2000). A preliminary phylogenetic analysis of Metapenaeopsis; Decapoda ; Paenaeidae; based on mitochondrial DNA sequences of selected species from the Indo-West Pacific. Journal of Crustacean Biology 20(3): 541-549.

Tzeng, T.D., Chiu C.S. and Yeh, S.Y. (2001). Morphometric variation of Metapenaepsis barbata in different geographic waters of Taiwan. Fisheries Research 53: 211-217.

Waldman, J.R., Grossfield, J. and Wrigin, I. (1988). Review of stock discrimination techniques for striped bass. North American Journal of Fisheries Managements 8: 410-425.

Wowor, D. and Ng, P.K.L. (2007). The Giant Freshwater Prawns of Macrobrachium rosenbergii species group (Crustacea; Decapoda : Caridea : Palaemonidae). The Raffles Bulletin of Zoology 55: 321-336.

Zar, J.H. (1984). Biostatistical Analysis. $2^{\text {nd }}$ Edition; New Jersey; Prentice - Hall. 